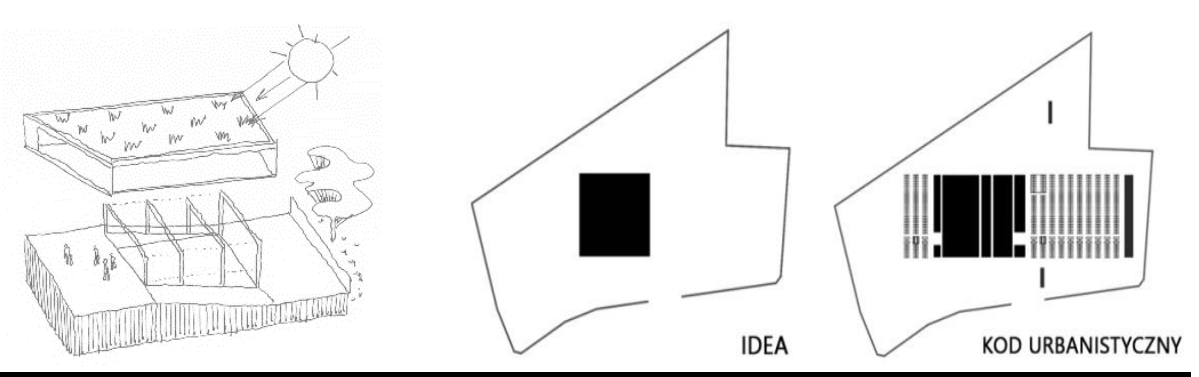

DOI: 10.21005/pif.2021.45.B-03

\title{
INTUITION AND DEDUCTION IN THE PROCESS OF EXPLAINING THE CORRECTNESS OF PROOF IN ARCHITECTURAL DIAGRAMS
}

\section{INTUICJA I DEDUKCJA W PROCESIE WYJAŚNIANIA POPRAWNOŚCI DOWODU W DIAGRAMACH ARCHITEKTONICZNYCH}

\author{
Paweł Maryńczuk \\ dr inż. arch. \\ Author's Orcid number: 0000-0003-0627-3061 \\ Andrzej Frycz Modrzewski Krakow University \\ Faculty of Architecture and Fine Arts
}

\begin{abstract}
Creating diagrams is an occasion for a sophisticated analysis of notions and exploring their meaning. It is also a form of direct contact with psychological phenomena and juxtaposing intuition and deduction as sources of cognition. Analysis of the development of philosophical stances can present the process of a departure from the classical view that holds that this argumentation can have a purely formal character (while the role of intuition is significantly reduced). The by-product shall be an explanation of often encountered simplifications associated with understanding both positions associated with their extreme versions: the intuitive relict or the version of formalism that produces an impression of being a sterile and even absurd argument. I argue in favour of the utility of both positions, as they can present interesting aspects of certain problems in architectural proofs at different stages of design, and used to distinguish different diagrams.
\end{abstract}

Key words: architectural diagrams, intuition and deduction, philosophical concepts, knowledge, reasoning, architectural evidence.

\section{STRESZCZENIE}

Tworzenie diagramów to okazja do wyrafinowanej analizy pojęć i swoistego wnikania w ich treść. To również bezpośredni kontakt ze zjawiskami o charakterze psychologicznymi i przeciwstawieniem intuicji i dedukcji, jako źródeł poznania. Analiza rozwoju stanowisk filozoficznych pozwoli na ukazanie procesu odchodzenia od poglądu klasycznego w myśl, którego w sposób intuicyjny ujmujemy poszczególne etapy rozumowania na rzecz poglądu zgodnie, z którym ta argumentacja może mieć charakter czysto formalny (zaś rola intuicji zostaje mocno zredukowana). Natomiast „produktem ubocznym” będzie wyjaśnienie, pewnych często spotykanych uproszczeń związanych ze zrozumieniem obu stanowisk utożsamianych ze skrajnymi ich wersjami. Intuicyjnego reliktu bądź wersją formalizmu sprawiającej wrażenie, że jest to stanowisko jałowe i wręcz absurdalne. Chcę podkreślić użyteczność obu stanowisk, gdyż pozwalają one na ukazanie ciekawych aspektów problemów w dowodach architektonicznych, na rożnych etapach projektowania i wyodrębnienie różnych diagramów.

Słowa kluczowe: architektoniczne diagramy, intuicja I dedukcja, koncepcje filozoficzne, wiedza, rozumowanie, dowody architektoniczne. 


\section{INTRODUCTION}

When architects discuss diagrams and their content, they explore whether a diagram is deep, whether it explains a phenomenon or merely points to a certain fact, without providing an in-depth perspective of the nature of the problem. We discuss the content of recordings, even the aesthetic value of diagrams, the beauty of the drawing and the play of ideas included in it. The process of producing creative products - material creations or ideas that are seen as novel - is described as creative problem-solving. Despite the many different psychological concepts that explain its nature and that suggest that it can follow different patterns, certain properties of creative thinking appear to be obvious and can be investigated (Maryńczuk P., 2015). According to the current state of the art in praxeology or systems science in architectural studies, we can divide the subjective, artistic experience, from that which can be gauged objectively without prejudgement concerning this distinction. Architectural research aimed at enhancing design practice that I consider essential is empirical and experience-based.

The findings of this research have been used in design analyses to interpret, understand and explain designs and the application of design tools - diagrams - in the design process. This research subject was discussed during module classes taught at the Faculty of Architecture of the Silesian University of Technology in Gliwice, Poland, and was investigated by an expert team comprising research and teaching personnel. The research was in line with formulating architectural theory aimed at enhancing design techniques (ex ante) - as an assessment of the design process and of designs under preparation (Maryńczuk P., 2015).

There can be no doubt that when one 'practices' diagrammatic recordation in architecture, understanding strictly geometric architectural concepts and the process of identifying their interrelations and gaining insight into their content are of paramount significance. Architects use terms from systems theory and praxeology on the one hand, while on the other they utilise a sort of architectural jargon which is inseparable from professional experience and practice. This is why spatial order based on mathematical proportions and geometric solid composition has a well-founded tradition that dates back to antiquity.

Spatial order based on mathematical proportions and the composition of geometric masses has a well-grounded tradition that dates back to antiquity as there were aspirations to connect man's work with the order of nature, understood as the order of the universe. One of mathematics' distinctive characteristics is acknowledging facts concerning the objects it studies (such as numbers or geometric figures) solely on the basis of proof. The teacher's authority is not enough ('this is how it is!'), and neither is popular opinion ('everyone says so!'). It can be said that practicing diagrammatics is a highly sophisticated analysis of notions and, in a certain lofty sense, the study of the world of architectural ideas. Surely, it cannot be reduced to 'drawing designs' (which the process of design is often associated with, and not only by architecture students). There can also be no doubt that when we practice diagrammatic reasoning we deal with very interesting psychological phenomena, both in conducting one's own research and in tracing the outcomes of the work of others.

Particular attention can be focused on dichotomies that are typically associated with it: the juxtaposition of intuition and reasoning (particularly deduction) as sources of cognition or that which is intuitive and that which is notional in our cognition. It is these dichotomies, which refer to function or cognitive powers that I would like to discuss in light of studies on the appropriateness of architectural proof as featured in diagrams.

\section{CONCEPTS OF REASONING AND PROVING}

\section{The classical view}

To understand the essence of this problem is to understand the nature of acts and explain semantic aspects, for they play a fundamental part in their creation.

The criterion of truth, as formulated by Descartes, and which forms the basis of his epistemology, is of fundamental significance to the problem under discussion. It posits that the basis of our cognition 
is the capacity to intellectually formulate certain obvious truths that appear before us in a clear and explicit manner. This is mentioned in the first of four principles that are fundamental to our thinking as argued by Descartes (Descartes R., 2002). This criterion is applied in mathematics: mathematical truths appear before us in a clear and explicit manner, which is to be proof of their truthfulness. In Descartes' view, the source of knowledge is our mind. The fundamental actions of our mind with which we can, without risk of error, attain cognition of a given object, are intuition and deduction.

By intuition, Descartes did '(...) not mean the fluctuating testimony of the senses or the deceptive judgment of the imagination as it botches things together, but the conception of a clear and attentive mind, which is so easy and distinct that there can be no room for doubt about what we are understanding' (Descartes R., 1957). Intuitive cognition, which includes mathematical cognition, is a purely intellectual act. Metaphorically speaking, it is viewing the world directly via the eyes of the mind.

The second fundamental activity of the mind is deduction, with which we can necessarily and surely draw a conclusion from things that are known to us. However, deduction is not in opposition to intuition. In deduction, we also have elements of intuitively perceiving the truthfulness of the argument being deducted at a specific step (one could say: the obviousness and justification of a given step).

Here, Descartes wrote of a continuous motion of thoughts in which we intuitively and clearly frame individual stages of inference. He explicitly wrote that fundamental truths (first principles) are learned through intuition, while conclusions derived from them, by deduction. Descartes' views are a model example of a content-based perspective on mathematical proofs, from which modern mathematics has been partially departing (Descartes R., 1957).

It should be remembered that Descartes did not distinguish mathematical knowledge as a specific fragment of our knowledge that is independent of, for instance, knowledge about the physical world, and purely rational (analytical, a priori) mathematical knowledge.

Therefore, it can be stated that geometric truths apply to the real world. To Descartes, intuitive cognition, 'insight' into truthfulness pertains not only to mathematics itself, but also applies to a much larger field.

It can be said that the division into mathematical and non-mathematical cognition is not crisp. Intuition allows us to arrive at fundamental mathematical truths, but also at fundamental metaphysical truths, particularly the existence of God, our consciousness and the external world (Wójtowicz K., 2012).

Our mathematical knowledge is thus naturally ingrained into this entire system of beliefs. The same view can be considered classical in the history of philosophy.

The essence of this point of view can be presented to the reader on the example of geometry, the fundamental principle of architecture and its accompanying provisions. Space is projected onto the plane of the drawing. It is thanks to geometry that space can be understood as a composition of interrelated spatial elements. In the well-known school of elementary geometry, all types of observable, imaginative elements are very strongly engaged in proof. Sometimes all that is necessary to convincingly communicate the idea of a given proof is a sketch, while sometimes the (formal) explanation accompanying such a sketch appears to be almost superfluous. With a certain degree of overstatement, it can be said that certainty is gained not by writing down the proof, but by a sort of 'insight into the geometric essence of the matter' (Descartes R., 1957). Jean Victor Poncelet (17881867) expressed similar opinions and wrote that, in ordinary geometry, it is the figure that is described and it is never out of sight, as reasoning is always performed with the use of values and forms that are real and we never reach conclusions that cannot be reflected in our imagination or before our eyes using sensory objects (Detlefsen M., 2005). Irrespective of the exaggeration of this statement, there can be no doubt that we typically utilise a certain form of geometrical intuition, while our understanding of the situation is key in elementary geometrical reasoning. 


\section{The formalist view}

Descartes saw the source of knowledge in mathematical intuition. In this perspective, the step of mathematical reasoning had to be justified by intuitive perspective - in other words: we must have a continuous intellectual perspective of the subject of our research. The validity of a given proof and a given argumentation must be backed by content-based analyses instead of formal ones. The "content-based' view has been present in mathematics for a long time, and it can be said that, from a historical standpoint - it is a natural view. Poncelet's statement can be considered an expression (or, to sound caustic, a relic) of such an 'imagination-based' form of thinking.

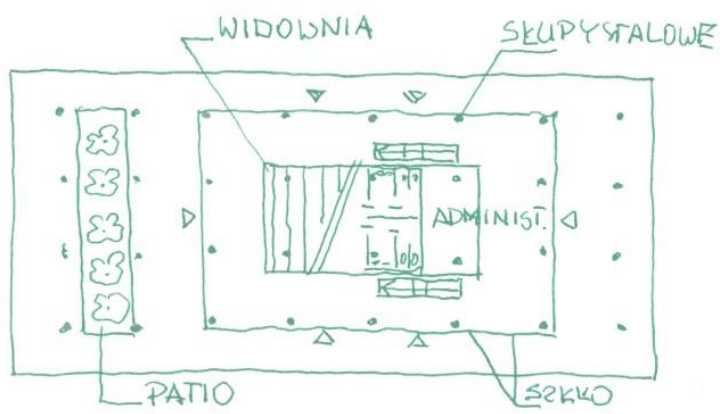

Fig. 1. Generative, three-dimensional diagram showing the record of the concept of the construction-phase design for the development of the architectural and urban concept of the Transfer Station in Żory, Source: Original work, 2018

Ryc. 1. Diagram generatywny, trójwymiarowy obrazujący zapis konceptu projektu realizacyjnego na opracowanie koncepcji architektoniczno - urbanistycznej Dworca Przesiadkowego w Żorach Żródło: Opracowanie autora 2018

Gradually, increasing significance is being ascribed to a different mode of thinking about the process of reasoning in mathematics. In this new perspective, there is a departure from the vision of mathematical proof as a process based on reliable and clear intuitions that lead us through all stadia of a given proof. The contemplation of eternal mathematical proofs is replaced mechanical, non-intuitive operations on symbols. Of course, this change did not take place suddenly, but was instead a product of a certain evolution in which the postulate of 'content control' over the subject of reasoning was gradually abandoned in favour of the postulate of following certain rules that are not linked with the subject under analysis in a content-based manner and have a rather external character (and typically a general one) (Wójtowicz K., 2012). This is clearly visible on the example of geometry, where the postulate of 'intuitive insight' was replaced by the postulate of formulating proof that satisfies certain purely formal requirements. In this context, of particular note are Pasch and Hilbert's studies in which this change in paradigm appears important.

Pasch wrote that if geometry is to be a truly deductive science, the process of reasoning must be independent of the meaning of geometric terms in all fragments, similarly as it must be independent of diagrams. In his view, only relations expressed in arguments and definitions must be taken into account. When engaging in reasoning, it is useful and permitted - but not necessary - to think about the meanings of specific terms. In his view, if it is necessary, then this shows the incorrectness of the argument (Pasch M.1980). The postulate of eliminating elements that are 'imaginative and apparent' (and - de facto - even references to the content of definitions) is radically different from the postulate of intuitive control over the steps of formulating proof. Proofs, particularly geometric proofs can (and should!) be treated in a purely formal manner, similarly to the transformation of algebraic expressions following formal rules. However, if we have to reference our understanding of a specific term and our intuitive perception of a situation, then this means there is a gap in the proof we are arguing for (Hahn H., 1980). 

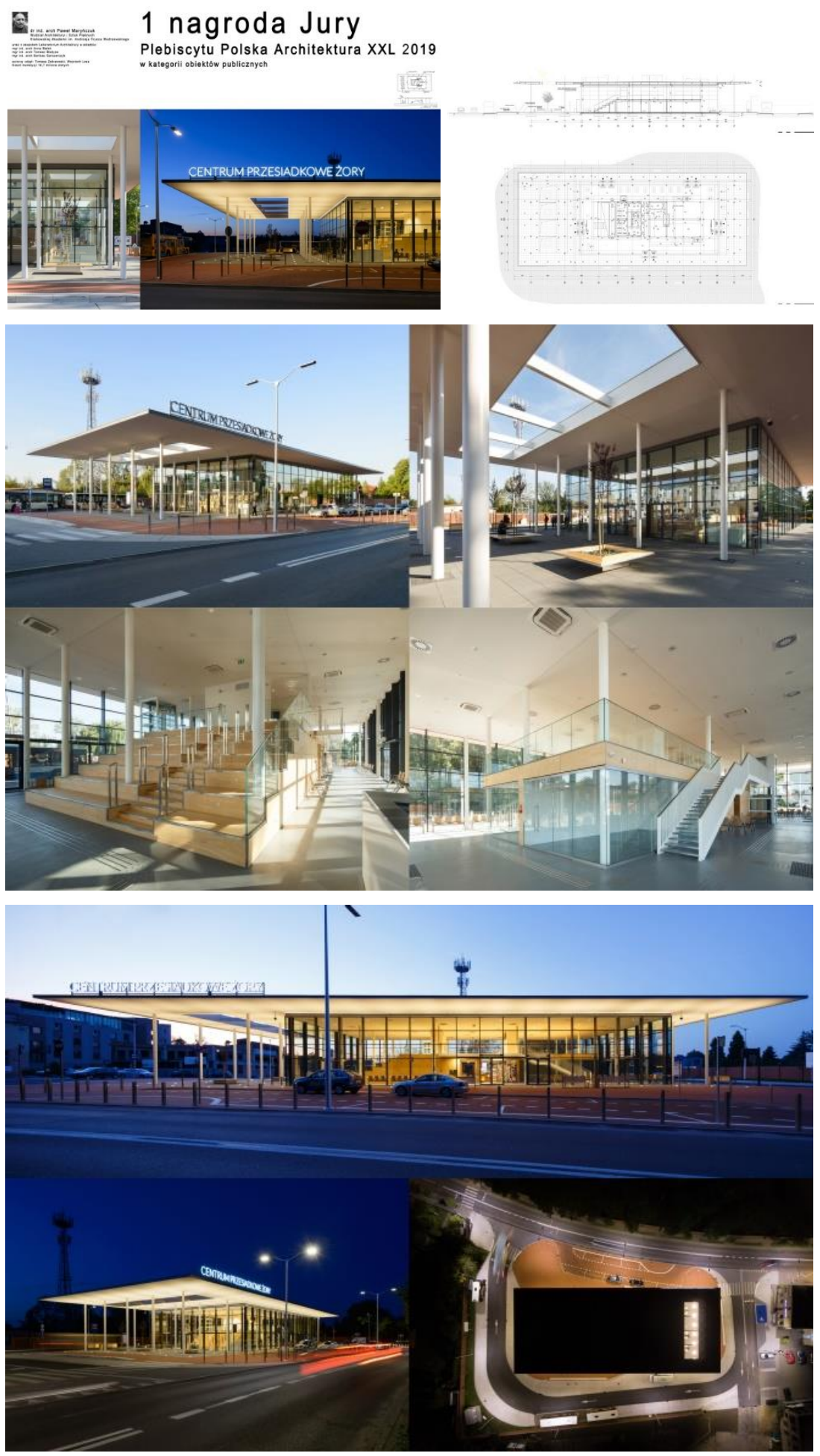

Fig. 2. Sheets from an exhibition at the Faculty of Architecture and Fine Arts in Krakow showing the building of the Transfer Station in Żory, which won the main award of the Polish Architecture XXL 2019 Plebiscite in the category of public buildings. Source: Original work, 2020. This is an example of a work that proves the effectiveness of the adopted design method based on evidence and diagram records in architectural practice

Ryc. 2. Plansze z wystawy na Wydziale Architektury i Sztuk Pięknych w Krakowie obrazujące obiekt Dworca Przesiadkowego w Żorach nagrodzonego główną nagroda Plebiscytu Polska Architektura XXL 2019 w kategorii obiektów publicznych. To przykład pracy, która jest dowodem skuteczności przyjętej metody projektowania w oparciu o dowody i zapisy diagramowe w praktyce architekta. Źródło: Opracowanie autora 2020 
The process of the departure from Descartes' 'content-based' perspective on mathematical proof was described by Hahn. He wrote that intuition had proven to guide astray in numerous cases and arguments that had been accepted based on intuition were proven false (based on logical reasoning), and mathematicians became increasingly sceptical of intuition. They recognised that it is not safe to base any mathematical argument on it (Hahn H., 1980).

We also have the 'Cartesian' perspective, which accentuates the role of intellectual acts and the 'formalist' perspective, which accentuates the necessity of formalising geometric proofs and provides formal criteria.

\section{ARCHITECTURAL DIAGRAM FROM A CLASSICAL AND FORMALIST PERSPECTIVE}

In a situation when geometric intuition has ceased to justify (act as a condition of) the validity of a proof, the need to remove ambiguities concerning proving methods and determining standards of practicing diagrammatics appears to be clear. The definitions and principles formulated below by the author have the character of such methodological standards in the proving process. This need to determine standards applies not only to geometry, architecture or other sciences - a similar process has taken place in the case of analysis. This has made it possible to deal away with argumentations based on intuitions in favour of argumentations based on calculations and the formal transformation of expressions (Wójtowicz K., 2012). We know that each phase in operating on models of the design process has its final outcome in a specific form of a record that reflects the precision of the problem, argument and thematic scope that is the subject of design work.

As designers, we know that we must enhance our working memory via external support. Historically speaking, the most important tool of this type is the sketch, while today the blackboard, piece of paper or transparency paper is often replaced by a computer screen. During the reasoning phase, as new information is generated or referenced in the proof, we incorporate them into the sketch and thus collect an increasing store of knowledge about the problem. However, sketches offer only a partial solution to the problem, for not all data can be visualised at the same time and certain fragments can be focused on at a time. All this is done only to come to the realisation that the problem of referencing information is simply transferred from long-term and working memory onto our drawing (Larkin J. H., Simon H.A. 1987).
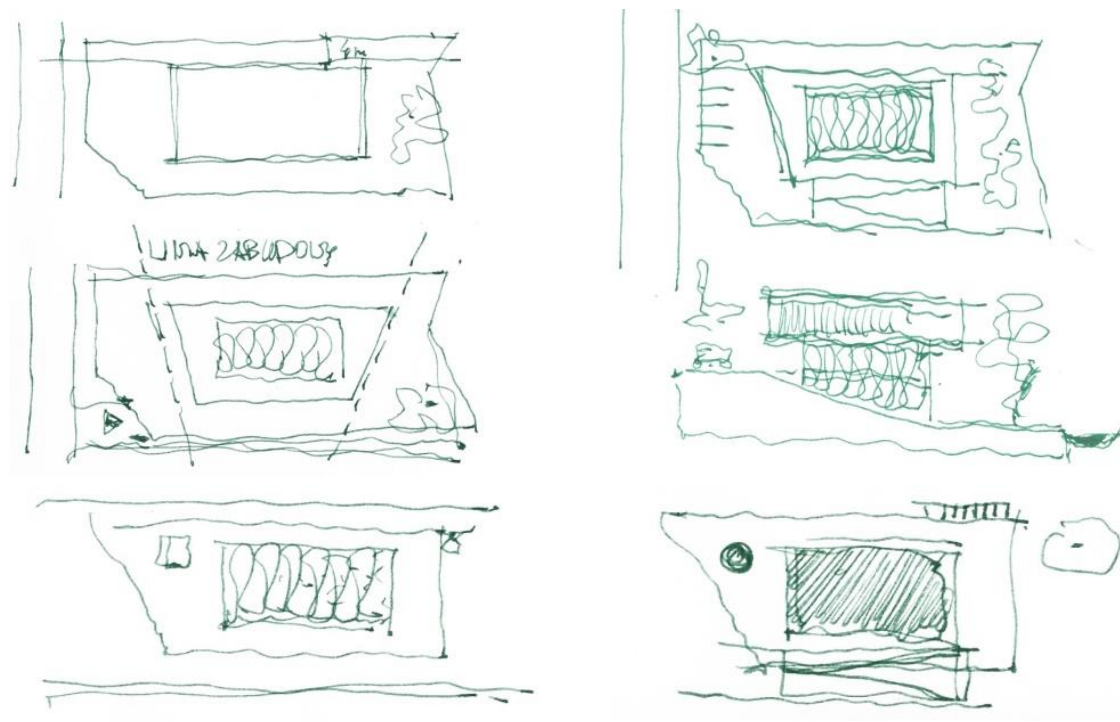

Fig. $3,4,5,6,7,8$. Sequences of a series of choices noted in sketches. The successive cycles allow for correct inference in architectural proof. Source: Original work, 2020

Ryc. 3,4,4,6,7,8. Sekwencje serii wyborów odnotowanych w szkicach. Kolejne cykle umożliwiają prawidłowe wnioskowanie w dowodzie architektonicznym. Źródło: Opracowanie autora 2020 
Fig. 9. Generative, three-dimensional diagram illustrating the notation of the concept of a concstruction-phase design of a complex of specialist clinics with a generally accessible pharmacy in Katowice. Source: Original work, 2020

Ryc. 9. Diagram generatywny, trójwymiarowy obrazujący zapis konceptu projektu realizacyjnego na opracowanie obiektu przychodni specjalistycznych z apteką ogólnodostępną w Katowicach. Żródło: Opracowanie autora 2020
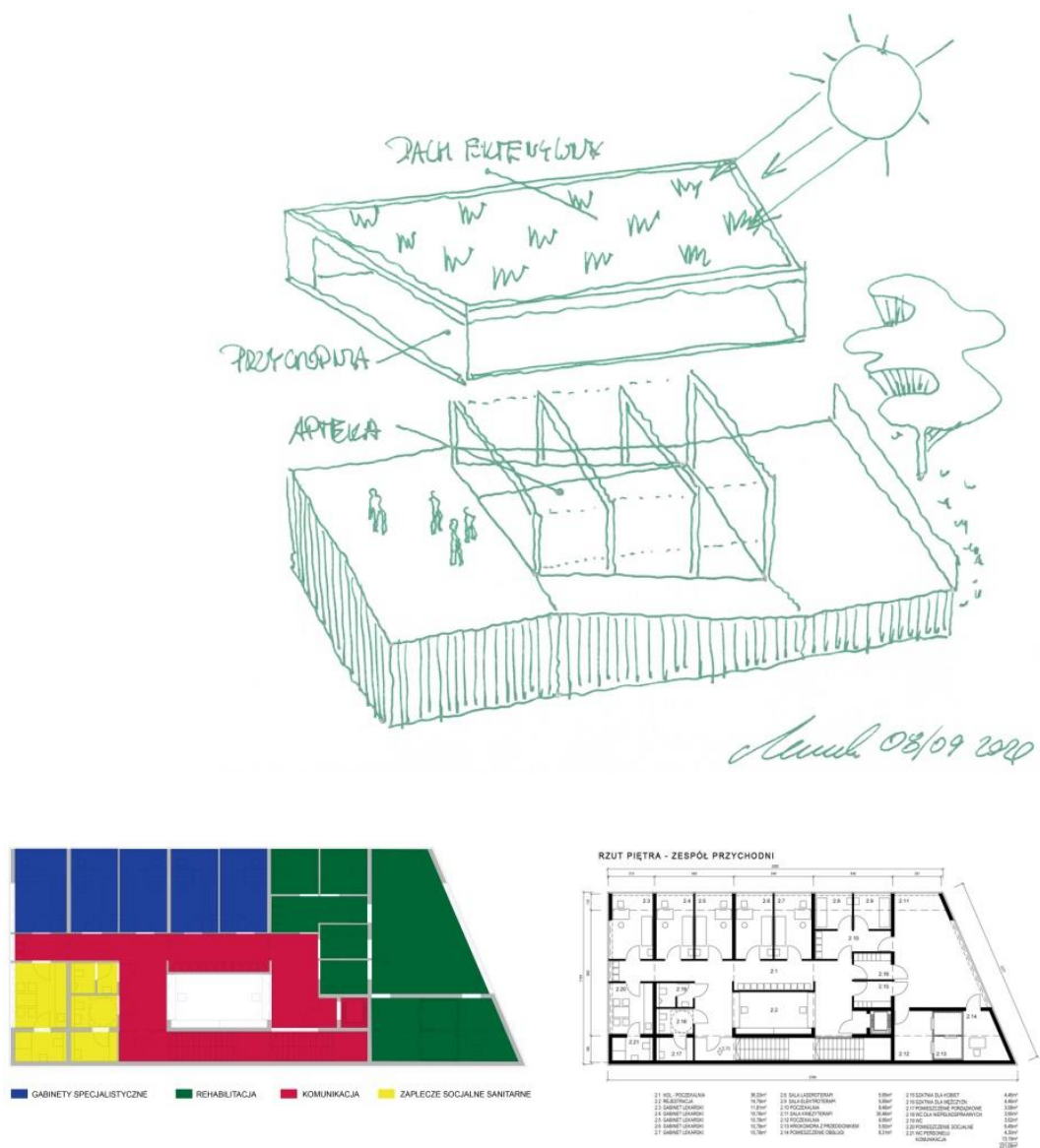

the construct of an architectura proposal made accord- ing to formalised principles and rules. Source: Original work, 2020 Ryc. 10,11,12,13. Elementy konstruktu koncepcji architektonicznej wykonane wg sformalizowanych zasad i reguł. Żródło: Opracowanie autora 2020

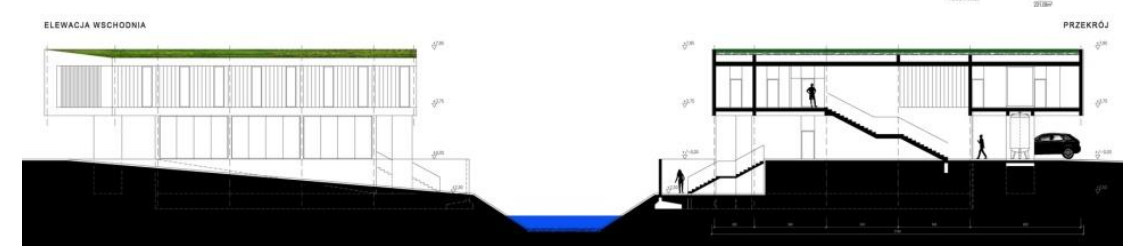

The problem itself remains unsolved, while the base of information that can be accessed at a given moment of concentration remains limited. However, the sketch does not lose the characteristics of spontaneity, and everything is achieved via the quickness of transferring forms created in one's imagination to the means of expression that is the plane of the drawing. Drawing the sketch is nevertheless something more than merely recording the proof and collecting information. From the 'Cartesian' perspective, it also allows us to infer conclusions, which would be difficult or impossible without its aid (or without a proper image that appears in the mind). This takes place because the intuitive character of the message is achieved due to the quickness of processing thought into the drawing. We can imagine a rectangle whose base is twice as long as its height. We can then place a vertical line that connects the centres of the longer sides of the rectangle. The question is: what are the shapes created by the division of the rectangle? This question can be easily answered: 'they are squares, of course'. However, can we make sure of it and prove this?

Let us go a step further, using the same example. Let us place a line that connects two corners of the rectangle. Does the diagonal intersect with the vertical line that we have previously placed (or only imagined)? Of course it does. How do we know this? We can see the point of intersection. The drawing or its image in the mind creates new objects (i.e. points) and relations between objects (i.e. 
line intersections), which would be very difficult to obtain using logical or mathematical inference. Furthermore, the drawing, regardless of the fact that it is a form of storing information in the proof, is also an efficient inference mechanism. We perform a series of choices that we record in the sketch. The sketch effortlessly 'calculates' many of the consequences of the mutual impacts of our choices. As sketches can be analysed in any design phase, we should be aware that connections between its elements can provide new information, e.g. concerning important details, conditions that were previously unaccounted for, alternatives that were not considered, etc. This is information that did not fit in the field of our observation during the previous round of decision-making. The use of this recall mechanism can often guarantee that the final outcome of design has accounted for a broad range of circumstances that would not be possible to simultaneously include. This cycle does not require the sole use of drawings.

Inference using the sketch has of course its own serious limitations. During the design problem identification phase, we are often forced to supplement the sketch with verbal descriptions, graphical symbols, graphs, mathematical formulas, three-dimensional spatial compositions and even photographs, painterly elements, etc. While doing so we enhance its legibility to the point when we assume it is complete. We create drawings distinctive of this form of documentation, which I set apart from the broad notion of the diagram and label them as generative diagrams. This course of inference in architectural proving, in Descartes' perspective, cannot have a formal character. Formal, symbolic operations can at most support the argumentation based on the intuitive perception of certain truths and their dependencies as presented in the diagram. We should also remember that our eyes are excellently adapted to viewing drawings or other visual depictions and to detect highly diverse relationships between these elements.

This postulate of an intuitive, content-based formulation of all stages of reasoning is distinctive for a certain form of thinking about the geometric proof - a manner of thinking that has been rejected by the proponents of the (broadly understood) formalist approach to reasoning.

Without a doubt, a significant impulse for changing the manner of thinking about geometry (particularly about proving standards in geometry) was the appearance of non-Euclidean geometry and its imaging techniques. In this new situation, the argument that states that geometry is merely a science about (physical) space based solely on our intuitions has become baseless. Geometry has become a science with certain structures detached from apparent interpretations and which form models for these geometric systems. It can be said that the idea that geometric theory describes a certain intended model is being abandoned in favour of thinking in categories that can be interpreted for theories. The removal of numerous limitations that are distinctive of manual drawings has been an important contribution of computer-aided design. One of the most significant of these was the twodimensional character of the drawing. The computer can store three-dimensional (or multi-dimensional) drawings. It can also, when necessary, present a sketch so that their three-dimensionality becomes obvious. We can free ourselves from all imaginary or visualisation-related elements which is a postulate maintained in an entirely 'anti-Cartesian' spirit. From the standpoint of the proof's strictness, 'content control' based on referencing intuition is irrelevant. Geometric, architectural proof can be treated in a purely formal manner.

The ability to accumulate information and automatically infer numerous conclusions about mutual relationships that we obtain due to using thus enhanced drawings, exerts a fundamental impact on the organisation of the design process. Design decisions based on this specialist reflection can be recorded and subsequently analysed from different standpoints than those that have been intuitively adopted while making each decision. I call a diagram that is analyzing and reflects a formalized construct analytical.

The analytical diagram's distinctive characteristic is its particularly strong emphasis on the cognitive process. It is essential that the diagram can be formulated no earlier than at the end of the conceptual design stage, when we are able to formulate proof that justifies certain purely formal requirements. It should be noted that both generative and analytical diagrams present a complex composition of elements that form a multi-layered system of defined problems that must be solved in parallel or in a specific sequence. The mutual placement of these internal visualisation elements that are included in the proving order form their composition as a form in space. 


\section{CONCLUSION}

It is an indisputable fact that when arguments are proven in the manner we know from common geometric practice, understanding geometric notions and grasping the relationships between them plays a fundamental role. When describing proofs included in architectural diagrams based on geometry, we use notions such as the idea of proof, we state that the proof explains the phenomena that interest us or that it merely points to a certain fact, leaving a feeling of cognitive insufficiency. It can be said, rather bombastically, that architects often perform a sort of contemplation of proofs in their diagrams, through which these proofs discover certain hidden, deep meanings, content, ideas or concepts. This is not about tracing technical details (e.g. whether the structural system is correct) but rather about acts - about 'insight into the essence of the argument'. In this image, the basis for proving (and thus the transfer of truth from assumptions to arguments) comprises intellectual acts and the key to understanding the nature of diagrammatic proof is explaining the semantics of the notions of architectural and geometric discourse.

On the other hand, we know that one of the distinctive features of mathematical proofs is that they can be formalised. Proofs known from practice are formulated in 'the natural geometric language', which is a sort of mixture of a symbolic and formal language. We thus have two visions of proofs and inferences that can be the starting point for further analyses in architectural proofs and two that pertain to the manner of recordation.

- (Architectural) Proving is a certain intellectual activity that is not constrained by purely formal conditions. The formal (or even language) layer is less essential. The communication of certain content, a certain idea, an intuition - and not formalisation - is key to geometry. Proving is instead more of a sequence of intellectual acts instead of formal transformations.

- From the classical point of view proving consists in operations on notions recorded in generative diagrams.

- (Architectural) proof, is a formal construct whose semantic aspects are irrelevant; what counts is compliance with formal rules. The fact that we can associate certain types of content with these proofs is a certain (and perhaps interesting) psychological phenomenon, although it is irrelevant in reasoning.

- From this point of view, the formal construct is recorded in analytical diagrams.

\section{INTUICJA I DEDUKCJA W PROCESIE WYJAŚNIANIA POPRAWNOŚCI DOWODU W DIAGRAMACH ARCHITEKTONICZNYCH}

\section{WSTĘP}

Gdy architekci mówią o diagramach i zawartych w nich treściach, zastanawiają się nad tym, czy diagram jest głęboki, czy wyjaśnia zjawiska, czy jedynie wykazuje pewien fakt, nie dając głębszego wglądu w naturę zagadnienia. Mówimy o treści zapisów, a nawet o estetycznych wartościach diagramów, o swoistym pięknie rysunku i zawartym w nim grze idei. Proces, dzięki któremu powstają twórcze produkty - materialne wytwory lub idee charakteryzujące się nowością, określa się jako twórcze rozwiazywanie problemów. Mimo wielości koncepcji psychologicznych wyjaśniających naturę takiego procesu, sugerujących, że może on przebiegać według różnych wzorów, pewne właściwości myślenia twórczego wydają się oczywiste i możliwe do zbadania (Maryńczuk P., 2015). Zgodnie ze współczesną wiedzą m.in. prakseologiczną, systemową w badaniach architektonicznych 
można oddzielić to co subiektywne czyli np. przeżycia artystyczne, od tego, co jest możliwe od poznania obiektywnego, nie przesadzając z góry o takim podziale. Wśród badań w architekturze nacelowanych na doskonalenie praktyki projektowej dla autora istotne są badania empiryczne, oparte na doświadczeniu.

Wyniki wspomnianych badań wykorzystane zostały w analizach projektowych celem interpretowania, zrozumienia, objaśnienia projektu i użycia narzędzi projektowych - diagramów wewnątrz procesu projektowego. Taki temat badawczy został poruszony wokół ćwiczeń kursowych na Wydziale Architektury Politechniki Śląskiej w Gliwicach i prowadzony był przez zespół ekspercki pracowników naukowo dydaktycznych.. Badania te mieściły się w nurcie zmierzającym do tworzenia tzw. teorii architektury nakierowanej na doskonalenie warsztatu projektowego (ex ante) - inaczej mówiąc ocenie procesu projektowego i projektu będącego w przygotowaniu (Maryńczuk P., 2015).

Nie ulega wątpliwości, że przy „uprawianiu” zapisów diagramowych w architekturze zasadnicze znaczenie ma rozumienie pojęć architektonicznych ściśle powiązanych z geometrią, proces identyfikowania relacji między nimi i swoistego „wnikania” w ich treść.. Architekci używają z jednej strony pojęć należących do teorii systemu i prakseologii, a z drugiej swoistego żargonu architektonicznego, jako niezbywalnie związanego $z$ doświadczeniem i praktyką zawodową. Dlatego ład przestrzenny oparty na proporcjach matematycznych i kompozycji brył geometrycznych ma silnie ugruntowaną tradycję sięgającą starożytności, gdy aspirowano do powiązania twórczości człowieka z porządkiem natury, rozumianym jako ład wszechświata. Cechą charakterystyczną matematyki jest uznawanie faktów dotyczących badanych przez nią obiektów (takich jak liczby czy figury geometryczne) wyłącznie na podstawie dowodów. Nie wystarczy autorytet nauczyciela („tak właśnie jest!”) ani nawet powszechna opinia („wszyscy tak mówią!”). Można powiedzieć, że uprawianie diagramatyki to bardzo wyrafinowana analiza pojęć i mówiąc nieco górnolotnie, badanie świata idei architektonicznych. Z całą pewnością nie sprowadza się do „rysowania projektów”, (z czym niekiedy kojarzy się proces projektowania nie tylko studentom architektury). Nie ulega też wątpliwości, że przy uprawianiu diagramatyki mamy do czynienia z bardzo ciekawymi zjawiskami o charakterze psychologicznym zarówno przy prowadzeniu własnych badań, jak i przy śledzeniu wyników czyjejś pracy.

Szczególną uwagę zwrócić można na dychotomie, które zazwyczaj są z nią wiązane: przeciwstawienie intuicji i rozumowania (w szczególności dedukcji), jako źródeł poznania czy tego co intuicyjne i tego, co pojęciowe w naszym poznaniu. Dychotomie te, odnoszące się do funkcji lub władz poznawczych, chciałbym rozważyć w świetle badań nad poprawnością dowodu architektonicznego zawartego w diagramach.

\section{KONCEPCJE ROZUMOWANIA I DOWODZENIA}

\section{Pogląd klasyczny}

Zrozumieć istotę tego zagadnienia to zrozumieć naturę aktów i wyjaśnić aspekty semantyczne, bo to one odgrywają zasadniczą rolę w ich tworzeniu.

Dla podjętego w niniejszym artykule problemu fundamentalne znaczenie ma przyjęte przez Kartezjusza kryterium prawdy, które stanowi podstawę jego epistemologii. Podstawą naszego poznania ma być zdolność intelektualnego ujmowania, jako oczywistych pewnych prawd, które jawią się nam w sposób wyraźny i jasny. Mówi o tym pierwsza z podanych przez Kartezjusza czterech fundamentalnych dla naszego myślenia zasad (Descartes R., 2002). To kryterium znajduje zastosowanie w działach matematyki: prawdy matematyczne jawią się nam w jasny i wyraźny sposób i to właśnie stanowi gwarancje ich prawdziwości. Źródłem wiedzy nie tylko matematycznej w ujęciu Kartezjusza jest, więc nasz rozum. Podstawowe czynności naszego umysłu za pomocą, których możemy, bez ryzyka błędu, dojść do poznania danej rzeczy, to intuicja i dedukcja.

Intuicję Kartezjusz określa, jako ...nie zmienne świadectwo zmysłów, lub zwodniczy sąd źle tworzącej wyobraźni, lecz tak łatwe i wyraźne pojęcie umysłu czystego i uważnego, że o tym, co poznajemy, 
zgoła już wątpić nie możemy (Descartes R., 1957). Intuicyjne poznawanie, które obejmuje w szczególności poznanie matematyczne stanowi, więc pewien czysto intelektualny akt. Mówiąc metaforycznie, jest to bezpośrednie widzenie oczyma rozumu.

Drugą podstawową czynnością naszego umysłu jest dedukcja, dzięki której można z koniecznością, w sposób pewny wysnuć wniosek z rzeczy już wiadomych. Jednakże dedukcja nie jest bynajmniej przeciwstawna intuicji. Również w dedukcji mamy, bowiem do czynienia z elementami intuicyjnego postrzegania prawdziwości dedukowanego w danym kroku twierdzenia (można powiedzieć: oczywistości i prawomocności danego kroku).

Kartezjusz pisze tu o ciągłym ruchu myśli w ramach, którego w intuicyjny i wyraźny sposób ujmujemy poszczególne etapy rozumowania. Pisze wyraźnie o tym, że podstawowe prawdy (pierwsze zasady) poznajemy przy pomocy intuicji, natomiast wnioski z tych zasad przy pomocy dedukcji (Descartes R., 1957).

Poglądy Kartezjusza stanowią modelowy przykład treściowego ujęcia dowodu matematycznego, od którego matematyka nowożytna zacznie już niebawem odchodzić

Warto pamiętać, że Kartezjusz nie oddziela wiedzy matematycznej, jako szczególnego, wyróżnionego fragmentu naszej wiedzy, który jest niezależny od np. wiedzy dotyczącej świata fizycznego oraz wiedzę czysto racjonalną (analityczną, aprioryczną) wiedzę matematyczną. Można powiedzieć, że prawdy geometrii dotyczą realnego świata. U Kartezjusza intuicyjne poznanie, „wgląd” w prawdziwość dotyczy nie tylko samej matematyki, ale obejmuje znacznie szersza sferą.

Można powiedzieć, że podział na poznanie matematyczne i niematematyczne nie jest ostry. Intuicja pozwala nam na dotarcie do podstawowych prawd matematycznych, ale również do podstawowych prawd metafizycznych, w szczególności istnienia Boga, naszej jaźni, świata zewnętrznego. Nasza wiedza matematyczna wpisana jest, więc $w$ naturalny sposób $w$ ten cały system przekonań. Taki pogląd można uznać za klasyczny w historii filozofii (Wójtowicz K., 2012).

Istotę tego punktu widzenia można w czytelny sposób przedstawić na przykładzie geometrii, fundamentalnej zasady architektury i towarzyszących jej zapisów. Przestrzeń odwzorowywana jest na płaszczyźnie rysunku. To właśnie dzięki geometrii przestrzeń można rozpatrywać, jako kompozycję elementów przestrzennych pozostających we wzajemnych relacjach. W znanej wszystkim ze szkoły geometrii elementarnej wszelkiego typu elementy poglądowe, wyobrażeniowe są w dowodach angażowane w sposób bardzo silny. Niekiedy wystarczy szkic, aby przekazać ideę dowodu w sposób przekonujący, zaś towarzyszące owemu szkicowi wyjaśnienia (formalne) wydają się być nieomalże zbędne. Mówiąc z pewną przesadą: pewność uzyskujemy nie poprzez wypisanie dowodu, ale poprzez swoisty „wgląd w geometryczną istotę zagadnienia” (Descartes R., 1957). Wyrazicielem tego typu opinii jest np. Jean Victor Poncelet (1788-1867), który pisał: „W zwykłej geometrii [...] opisywana jest figura, nigdy nie tracimy jej z oczu, zawsze rozumujemy $z$ użyciem wielkości i form, które są rzeczywiste i nigdy nie dochodzimy do wniosków, które nie mogą być odzwierciedlone w wyobraźni lub przed naszymi oczyma za pomocą obiektów zmysłowych" (Detlefsen M., 2005). Niezależnie od przesadności tego stwierdzenia, nie ulega wątpliwości, że zazwyczaj odwołujemy się do pewnej formy geometrycznej intuicji, zaś rozumienie sytuacji jest kluczowe w elementarnych rozumowaniach geometrycznych.

\section{Pogląd formalistyczny}

Kartezjusz źródło wiedzy upatrywał w intuicji matematycznej. W takim ujęciu krok rozumowania matematycznego musiał być uprawomocniony przez intuicyjny ogląd - czy mówiąc inaczej: musimy mieć stały ogląd intelektualny przedmiotu naszego badania. O prawomocności dowodu i danej argumentacji świadczyć muszą analizy o charakterze treściowym, a nie formalnym. Pogląd "treściowy" był obecny w matematyce przez długi czas, można powiedzieć, że z historycznego punktu widzenia - jest to pogląd naturalny. Wyrazem (a mówiąc złośliwie reliktem) takiego „wyobrażeniowego” myślenia jest wspomniane stwierdzenie Ponceleta. Stopniowo coraz większe znaczenie zyskuje inny pogląd myślenia o procesie wnioskowania w matematyce. W tym nowym ujęciu odchodzi się od wizji dowodu matematycznego, jako procesu opierającego się na niezawodnych i jasnych intuicjach, które prowadzą nas przez wszystkie stadia dowodu. Mówiąc nieco górnolotnie, kontemplacja wiecznych 
prawd matematycznych zostaje zastąpiona przez mechanicznie, nieodwołujące się do intuicji działania na symbolach. Taka zmiana nie nastąpiła oczywiście w sposób nagły, raczej była wynikiem pewnej ewolucji, w której stopniowo odchodzono od postulatu „treściowej kontroli” nad przedmiotem rozumowania na rzecz postulatu postępowania zgodnie z pewnymi regułami, które nie są treściowo powiązane z przedmiotem analizy i mają charakter niejako zewnętrzny (i najczęściej ogólny) (Wójtowicz K., 2012).

Widać to bardzo wyraźnie na przykładzie geometrii, gdzie postulat „intuicyjnego wglądu” został zastąpiony postulatem możliwości sformułowania dowodu czyniącego zadość pewnym czysto formalnym wymaganiom. W tym kontekście warto wspomnieć o badaniach Pascha i Hilberta, w których ta zmiana paradygmatu staje się wyraźna. Pasch pisał: „Jeśli geometria ma naprawdę być nauką dedukcyjną, proces wnioskowania musi we wszystkich fragmentach być niezależny od znaczenia pojęć geometrycznych, podobnie jak musi być niezależny od diagramów; pod uwagę mogą być brane jedynie relacje wyrażane $w$ twierdzeniach i definicjach.

W czasie wnioskowania jest użyteczne i dopuszczalne, ale nie konieczne myślenie o znaczeniach terminów; faktycznie, jeśli jest to konieczne, to w ten sposób widoczna staje się niepoprawność dowodu”[9]. Postulat wyeliminowania elementów o charakterze „wyobrażeniowo-poglądowych” (i - de facto nawet odwołań do treści pojęć) jest radykalnie odmienny od postulatu intuicyjnej kontroli nad krokami dowodowymi. Przytoczony wcześniej pogląd Ponceleta, Pasch uznałby za całkowicie niedopuszczalny. Kontrola opierająca się na naszej intuicyjnej zdolności do postrzegania przejść dowodowych, jako prawomocnych nie ma znaczenia z punktu widzenia oceny poprawności dowodu.

Dowody w szczególności dowody geometryczne można (i należy!) traktować w czysto formalny sposób, podobnie jak przekształcanie wyrażeń algebraicznych zgodnie z regułami formalnymi. Jeśli zaś w jakimś dowodzie musielibyśmy odwołać się do naszego rozumienia treści pojęć i intuicyjnego postrzegania sytuacji, jest to świadectwo tego, że w dowodzie jest po prostu luka (Hahn H., 1980).

O procesie odchodzenia od kartezjańskiego, „treściowego” ujęcia dowodu matematycznego tak pisał Hahn: „Ponieważ intuicja okazała się zwodnicza w tak wielu przypadkach i ponieważ twierdzenia akceptowane na mocy intuicji okazywały się fałszywe (na mocy wnioskowania logicznego), matematycy stawali się coraz bardziej sceptyczni w odniesieniu do intuicji. Uznali, ze nie jest rzeczą bezpieczna opieranie jakiegokolwiek stwierdzenia matematycznego [...] na intuicyjnych przekonaniach (Hahn H., 1980). Mamy, zatem ujęcie „kartezjańskie”, akcentujące rolę aktów intelektualnych i ujęcie „formalistyczne”, akcentujące konieczność formalizacji dowodów geometrycznych i podające kryteria o charakterze formalnym.

\section{DIAGRAM ARCHITEKTONICZNY W UJĘCIU KLASYCZNYM I FORMALISTYCZNYM}

W sytuacji, gdy intuicja geometryczna przestała stanowić rękojmię (warunek) poprawności dowodu, coraz bardziej wyraźna staje się potrzeba usunięcia niejasności dotyczących metod dowodowych oraz ustalenia obowiązujących standardów uprawiania diagramatyki. Formułowane przez autora poniższe definicje i zasady mają właśnie charakter takich standardów metodologicznych w procesie dowodzenia. Ta potrzeba ustalenia standardów dotyczy oczywiście nie tylko geometrii, architektury czy innych nauk - podobny proces miał miejsce w przypadku analizy. To umożliwiło uwolnienie się od argumentacji opartych na intuicjach na rzecz argumentacji opartej na obliczeniach i formalnych przekształceniach wyrażeń (Wójtowicz K., 2012).

Wiemy, że każda faz w operacji w modelach procesu projektowania ma swój finał w postaci specyficznej formy zapisu odzwierciedlającej szczegółowość zakresu problemowego - dowodowego i tematycznego będącego przedmiotem działań projektowych.

Jako projektanci wiemy, że musimy powiększyć naszą pamięć roboczą wspomaganiem zewnętrznym. Historycznie rzecz ujmując, najważniejszym narzędziem tego rodzaju jest narysowany szkic, współcześnie zaś tablicę, kartę papieru czy kalki często zastępuje ekran monitora komputerowego. 
W fazie rozumowania, w miarę przywoływania lub generowania nowych informacji w dowodzie, włączamy je do szkicu i w ten sposób gromadzimy coraz większy zasób wiedzy o rozwiązywanym problemie. Szkice jednak tylko częściowo rozwiązują problem, okazuje się, że nie możemy ogarnąć wszystkich danych jednocześnie, że musimy skoncentrować się na pewnych jego fragmentach. Wszystko po to, aby przekonać się, że problem przywoływania informacji jest po prostu przeniesiony z pamięci trwałej i pamięci roboczej na nasz rysunek. Sam problem pozostaje nierozwiązany, a zasób informacji, które można ogarnąć w chwili koncentracji uwagi jest ciągle ograniczony. Przy czym szkic nie zatraca cech spontaniczności, a wszystko to osiągane jest dzięki szybkości przenoszenia form powstałych w wyobraźni na środek przekazu, jakim jest płaszczyzna rysunku (Larkin J. H., Simon H.A. 1987). Rysowanie szkicu jest jednak czymś więcej, aniżeli tylko rejestrowaniem dowodu i gromadzeniem informacji. W ujęciu „kartezjańskim” szkic pozwala również wyciągnąć wnioski, co byłoby trudne lub zgoła niemożliwe bez jego pomocy (lub bez odpowiedniego obrazu pojawiającego się w umyśle). Dzieje się tak, ponieważ intuicyjny charakter przekazu osiągnięty jest dzięki szybkości przetworzenia myśli na rysunek. Można wyobrazić sobie prostokąt, którego podstawa jest dwukrotnie dłuższa aniżeli wysokość. Można następnie przeprowadzić pionową linię łączącą środki dłuższych boków prostokąta. Pytanie brzmi: jaki kształt mają figury powstałe wskutek podziału prostokąta? Na to pytanie można odpowiedzieć bez wahania - ,oczywiście, są to kwadraty". Czy jednak można się o tym przekonać i czy można to udowodnić bez wyobrażenia pojawiającego się w umyśle lub bez posłużenia się rysunkiem?

Pójdźmy o krok dalej, wykorzystując ten sam przykład. Poprowadźmy linię łączącą dwa rogi prostokąta. Czy przekątna przecina pionową linię, którą poprowadziliśmy (lub tylko wyobraziliśmy sobie) poprzednio? Oczywiście tak. Skąd to wiadomo? Możemy zobaczyć punkt przecięcia. Otóż, rysunek lub jego obraz powstający w umyśle tworzy nowe obiekty (tj. punkty) i relacje między obiektami (tj. przecięcia się linii), które byłoby bardzo trudno uzyskać za pomocą wnioskowania logicznego lub matematycznego. Co więcej, rysunek niezależnie od tego, że stanowi sposób magazynowania informacji w dowodzie, jest ponadto wydajnym mechanizmem wnioskowania [5]. Dokonujemy serii wyborów, które odnotowujemy w szkicu. Szkic bez wysiłku „wylicza” wiele z konsekwencji wzajemnego oddziaływania dokonanych wyborów. Ponieważ szkice można analizować w dowolnej fazie procesu projektowania, należy liczyć się z tym, że powiązania między jego elementami dostarczą nowych informacji, np. dotyczących ważnych szczegółów, warunków, które nie zostały uwzględnione - wariantów, których nie wzięto pod uwagę itp.

Są to, zatem informacje, które nie pomieściły się w polu naszych obserwacji w trakcie wcześniejszego podejmowania decyzji.

Wielokrotnie zastosowanie takiego mechanizmu przywoływania może gwarantować, że w ostatecznym rezultacie projektowania wzięto pod uwagę szeroki zakres okoliczności, których w żaden sposób nie byliśmy w stanie uwzględnić jednocześnie. Cykl taki nie wymaga posługiwania się wyłącznie rysunkami.

Wnioskowanie przy użyciu szkicu ma oczywiście swoje poważne ograniczenia. W fazie identyfikacji problemu projektowego, szkic, niejednokrotnie zmuszeni jesteśmy uzupełnić, o opisy słowne, symbole graficzne, grafy, wzory matematyczne, trójwymiarowe kompozycje przestrzenne, a nawet fotografie, elementy malarskie itp. Poprawiamy tym samym jego czytelność, aż do momentu, gdy uznamy go za skończony. Tworzymy charakterystyczne dla takiego opracowania rysunki, które wyodrębniam z szerokiego pojęcia diagramu i nazywam diagramami generatywnymi. Taki przebieg rozumowania w dowodzie architektonicznym w ujęciu Kartezjusza nie może mieć charakteru czysto formalnego. Formalne, symboliczne operacje mogą, co najwyżej stanowić wsparcie dla argumentacji opartej na intuicyjnym postrzeganiu pewnych prawd i ich zależności przedstawionych w diagramie. Warto także pamiętać o tym, że nasze oczy są wspaniale przystosowane do przeglądania rysunków lub innych przedstawień wizualnych i do wychwytywania bardzo rozmaitych powiązań między ich elementami.

Ten postulat intuicyjnego, treściowego ujmowania wszystkich etapów rozumowania jest charakterystyczny dla pewnego sposobu myślenia o dowodzie geometrycznym - sposobu myślenia odrzuconego przez zwolenników (szeroko rozumianego) formalistycznego podejścia do procesu rozumowania. 
Niewątpliwie znaczącym impulsem dla zmiany sposobu myślenia o geometrii (w szczególności o standardach dowodowych w geometrii) było pojawienie się geometrii nieeuklidesowych jak i technik jej obrazowania. W tej nowej sytuacji teza głosząca, że geometria jest po prostu nauką o przestrzeni (fizycznej) oparta wyłącznie na naszych intuicjach przestała mieć racje bytu. Geometria stała się, bowiem nauką o pewnych strukturach, oderwanych od poglądowych interpretacji a stanowiących modele dla tych systemów geometrycznych. Można powiedzieć, że odchodzi się od idei, iż teoria geometryczna opisuje pewien model zamierzony, na rzecz myślenia w kategoriach możliwych interpretacji dla teorii [5]. Ważnym wkładem komputerowego wspomagania projektowania jest usunięcie wielu ograniczeń charakterystycznych dla rysunków odręcznych. W tym jednego z najważniejszych ograniczeń, tj. dwuwymiarowości rysunku. Komputer może gromadzić rysunki trójwymiarowe (lub wielowymiarowe). Potrafi on również, jeśli to konieczne, prezentować szkic tak, że ich trójwymiarowość staje się oczywista. Możemy uwolnić go od wszelkich elementów wyobrażeniowych, poglądowych, co stanowi postulat utrzymany w całkowicie „antykartezjańskim” duchu. Z punktu widzenia ścisłości dowodu, "treściowa kontrola”, oparta na odwołaniu się do intuicji, nie ma najmniejszego znaczenia. Dowód geometryczny, architektoniczny możemy traktować w czysto formalny sposób, Możliwość kumulowania informacji i automatycznego wyciągania wielu wniosków o wzajemnych powiązaniach, które uzyskujemy dzięki posługiwaniu się tak wzbogaconymi rysunkami, wywiera zasadniczy wpływ na organizację procesu projektowania. Decyzje projektowe oparte na tej specjalistycznej refleksji mogą być rejestrowane i kolejno analizowane z punktów widzenia odmiennych niż te, które zostały dotychczas intuicyjnie przyjęte w czasie podejmowania poszczególnych decyzji. Taki diagram, który ma charakter analizujący i jest odzwierciedleniem sformalizowanego konstruktu nazywam analitycznym.

Cechą charakterystyczną diagramu analitycznego jest szczególnie silny nacisk na proces poznawczy. Istotne jest to, że ten diagram może powstać nie wcześniej, jak na koniec etapu projektowania koncepcyjnego, gdy mamy możliwości sformułowania dowodu czyniącego zadość pewnym czysto formalnym wymaganiom. Należy zaznaczyć, że zarówno diagram generatywny jak i analityczny przedstawia złożoną kompozycję elementów tworzących wielowarstwowy układ zdefiniowanych problemów, które muszą być rozwiązywane równolegle lub w stosownej kolejności. Wzajemne usytuowanie elementów wizualizacji wewnętrznych objętych porządkiem dowodowym stanowi ich kompozycję w postaci formy w przestrzeni.

\section{POSUMOWANIE}

Jest bezspornym faktem, ze w dowodzeniu twierdzeń w taki sposób, jaki znamy ze zwykłej praktyki geometrycznej podstawową rolę odgrywa rozumienie pojęć geometrycznych i uchwycenie relacji miedzy nimi. Przy opisie dowodów zawartych w diagramach architektonicznych opartych na geometrii, posługujemy się takimi pojęciami jak idea dowodu, mówimy o tym, ze dowód wyjaśnia interesujące nas zjawiska, lub że jedynie wykazuje pewien fakt, pozostawiając uczucie poznawczego niedosytu. Nieco górnolotnie można powiedzieć, ze nierzadko architekci dokonują swoistej kontemplacji dowodów w diagramach, dzięki której owe dowody odkrywają pewne ukryte, głębokie znaczenia i treści, idee czy koncepcje. Nie chodzi przy tym o śledzenie szczegółów technicznych (takich jak np. to, czy układ konstrukcji jest poprawny), ale raczej o akty - można rzec - „wglądu w istotę dowodu”.

W takim obrazie, podstawa dowodzenia (i tym samym transferu prawdy od założeń do twierdzeń) są intelektualne akty a kluczem do zrozumienia natury dowodu diagramowego jest wyjaśnienie semantyki pojęć architektoniczno-geometrycznego dyskursu.

$Z$ drugiej jednak strony wiemy, że istotną cechą dowodów matematycznych jest ich formalizowalność. Znane z praktyki dowody sformułowane są w „naturalnym języku geometrycznym”, będącym swoistą mieszaniną języka symbolicznego i formalnego. Mamy, zatem niejako dwie wizje dowodów i rozumowań, które mogą być punktem wyjścia dla dalszych analiz w dowodach architektonicznych oraz dwa odpowiednio przypisane im sposoby zapisu.

- Dowodzenie architektoniczne stanowi swoistą aktywność intelektualną, która nie jest skrępowana warunkami czysto formalnymi. Sama warstwa formalna (czy nawet językowa) jest mniej 
istotna. Kluczowe dla geometrii jest przekazywanie pewnych treści, idei, intuicji, a nie formalizacja. Dowodzenie stanowi raczej ciąg aktów intelektualnych, a nie przekształceń formalnych.

- Z klasycznego punktu widzenia, dowodzenie to operacje na pojęciach zapisane w diagramach generatywnych.

- Dowód, architektoniczny to formalny konstrukt, którego semantyczne aspekty są nieistotne; liczy się tylko zgodność z formalnymi regułami, Fakt, że można powiązać z tymi dowodami pewne treści jest pewnym (być może skądinąd ciekawym) zjawiskiem psychologicznym, jednak nie ma ono żadnego znaczenia w rozumowaniach.

- $\quad Z$ tego punktu widzenia formalny konstrukt zapisywany jest $w$ diagramach analitycznych.

\section{BIBLIOGRAPHY}

Maryńczuk P., 2015; Wspomaganie twórczego projektowania metodą syntezy informacji. Gliwice. Wydawnictwo Śląsk.

Descartes R., 2002: Rozprawa o metodzie właściwego kierowania rozumem i poszukiwania prawdy w naukach. Kraków: Zielona Sowa.

Descartes R., 1957: Prawidła kierowania umysłem; poszukiwanie prawdy przez światło przyrodzone rozumu, tłum. L. Chmaj, Warszawa: PWN.

Detlefsen M., 2005: Formalism, [w:] The Oxford Handbook of Philosophy of Mathematics and Logic, (red.) S. Shapiro S., Oxford University Press, Oxford 2005.

Gajewski P., 2001: Zapisy myśli o przestrzeni. Politechnika Krakowska, Kraków 2001.

Gray J., 1989; Ideas of Space, Euclidean, Non-Euclidean and Relativistic, wyd. 2 Oxford; Oxford University Press.

Hahn H., 1980: Empiricism, Logic and Mathematics, D. Reidel, Dordrecht - London - Boston 1980.

Larkin J. H., Simon H.A. 1987: Why a diagram is (sa=omethimes) Worth Ten Thousand Words, Cognitive Science 11.

Pasch M.1980,: Vorlesungen über neuere Geometrie, Teubner, Leipzig 1882.

Wójtowicz K., 2012: O pojęciu dowodu w matematyce, seria monografie.

Fundacji Na Rzecz Nauki Polskiej, Wydawnictwo Naukowe UMK, Toruń 2012. 


\section{AUTHOR'S NOTE}

From 1988 the author continuously participates in teaching classes for students of the Faculty of Architecture. The theoretical and practical experiences that I have gained during previous research work have become the foundation for developing my own original research methodology for studies of the design process. The use of diagrammatic notation, as an extraordinarily effective tool in both professional work and teaching, is intended to serve this purpose.

\section{O AUTORZE}

Od 1988r. autor nieprzerwanie uczestniczy w prowadzeniu zajęć dydaktycznych dla studentów Wydziałów Architektury. Teoretyczne i praktyczne doświadczenia zdobyte w trakcie prowadzenia wcześniej omówionych prac badawczych były podstawą do przygotowania autorskiego warsztatu badawczego dla badań nad procesem projektowania. Służyć ma temu wykorzystanie zapisu diagramowego, jako niezwykle skutecznego narzędzia w pracy zawodowej jak i dydaktycznej.

Contact | Kontakt: m-projekt@vp.pl 